DOI https://doi.org/10.30525/978-9934-26-073-5-1-67

\title{
ПОЕТИКА ЗМІНЕНИХ СТАНІВ СВІДОМОСТІ: ТРАНСКУЛЬТУРНИЙ ТА ТРАНСДИСЦИПЛІНАРНИЙ АСПЕКТИ
}

\author{
Присяжнюк Л. Ф. \\ кандидат філологічних наук, \\ дочент кафедри англійської філології, перекладу і філософії мови \\ імені професора О. М. Мороховского \\ Київського національного лінгвістичного університету \\ м. Київ, Україна
}

Стрімкий розвиток інформаційно-комунікаційних технологій та зростання міжнародної міграції $є$ одними з найбільш важливих характеристик сучасного світового розвитку, які спричиняють трансформації усталених форм суспільного життя, видозмінюють відчуття людиною себе та світу, безпосередньо впливають на появу принципово інших проявів людської креативності. Усе це спонукає до пошуку альтернативних механізмів психічної адаптації до нової мінливої реальності, наприклад, змінених станів свідомості (далі - ЗСС) [12]. Останні розглядаються як резерв наших психічних можливостей, засіб самовдосконалення і духовного зростання [4; 11], який може вплинути на еволюцію людини як біологічного виду [6].

Новітні підходи до вивчення таких станів у межах лінгво- та когнітивно-поетологічних студій цілком відповідають тенденціям сучасного культурного й наукового розвитку та $є$ тісно пов'язаними 3 поняттями "транскультура" [7] і "трансдисциплінарність" [10, с. 48]. Необхідність залучення трансдисциплінарного підходу, в межах якого долаються штучні кордони між точними і гуманітарними науками [там само, с. 47], а логічне пояснення доповнюється ірраціональним досвідом, $\epsilon$ очевидною для вивчення свідомості та її станів, тобто явищ, які не можуть бути зведені до формальних структур, не вкладаються у формат традиційного типу логіки та вимагають поєднання раціонального й ірраціонального. У цьому зв'язку саме в мистецтві вбачається можливість віднайдення ширшого спектру способів осмислення світу [9, с. 15], характерних для чуттєвого, дораціонального, емоційного рівня свідомості. Прикладами може слугувати художнє втілення незвичайних станів свідомості: візіонерського досвіду, онейричних станів, досвіду людини у віртуальному середовищі тощо. 
Водночас гнучкість трансдисциплінарного підходу полягає i y визнанні важливості "моно"дисциплінарності. Ці два підходи можуть доповнювати один одного при вирішенні складних наукових проблем. Таким чином, розробка теоретичних засад i методологічного апарату дослідження ЗСС передбачає як комплексний підхід, так і виділення вузькоспеціалізованих аспектів цього явища.

Застосування поняття "транскультура" до вивчення художньої реалізації ЗСС видається важливим у контексті транскультурної прози, пов'язаної з гібридною художньою ідентичністю [8]. Крім того, слід зазначити наявність культурно-детермінованих відмінностей у сприйнятті ЗСС. Так, наприклад, для індіанського світобачення не існує характерного для європейської культури чіткого протиставлення реальність - нереальність [2, с. 67]. У деяких культурах сон сприймається як більш особистісна частина реального [там само, с. 67], відповідно, поіншому вибудовується і шкала ЗСС.

Специфіка втілення ЗСС саме в транскультурній прозі простежується в семантиці гібридного художнього образу, домінантною рисою якого $\epsilon$ поєднання декількох культурних традицій образогенезу, та у використанні специфічних наративних технік зображення художньої свідомості, як от психонаратив [3], наративний хаос [1, с. 15], пов'язаний 3 часопросторовою дезорієнтацією [5] та розмиванням кордонів між відносно нормальними станами свідомості та відхиленнями від них.

\section{Література:}

1. Бабелюк О.А. Поетика спонтанності постмодерністського наративу Записки з романо-германської філології. 2015. Вип. 1. С. 15-24.

2. Гордеева О.В. Измененные состояния сознания и культура: основные проблемы и направления исследований в современной психологии. Измененные состояния сознания и культура: Хрестоматия. СПб.: 2009. С. 4-28.

3. Ізотова Н. П. Семантика психонаративу в контексті сюжетотворення (на матеріалі романів Дж. М. Кутзее). Наукові записки Кіровоградського державного педагогічного університету імені Володимира Винниченка. 2015. № 138. С. 331-336.

4. Котлер С., Уіл Дж. Викрадачі вогню. Таємна революція змінених станів. К., 2017. 272 с.

5. Присяжнюк Л. Ф. Оніричний хронотоп сучасної англомовної крос-культурної прози: нарис із лінгвістичної психопоетики. Науковий вісник ДДПУ імені I. Франка. Серія «Філологічні науки». 2017. № 7. C. 140-153. 
6. Спивак Л. И., Спивак Д. Л. Изменённые состояния сознания: типология, семиотика, психофизиология. Сознание $u$ физическая реальность. 1996. Т. 1, N 4. С. 48-55.

7. Тлостанова М. В. Транскультурация как модель социокультурной динамики. Вопросы социальной теории. 2011. Том V. С. 126-149.

8. Толкачев С. П. Гибридная образность в русской и английской постколониальной литературе. Филология и культура. 2017. № 2(48). C 193-200.

9. Черниговская Т. В. Чеширская улыбка кота Шредингера: язык и сознание. М., 2013. 448 с.

10. Эпштейн М. Н. Проективный словарь гуманитарных наук. M., 2017. $616 \mathrm{c}$.

11. Grof S., Grof Ch. Beyond Death: The Gates of Consciousness. L., $1980.96 \mathrm{p}$.

12. Ludwig A. M. Altered States of Consciousness. Archives of General Psychiatry. 1966. Vol. 15 (3). P. 225-234.

DOI https://doi.org/10.30525/978-9934-26-073-5-1-68

\title{
THE FUNCTION OF ANTINOMIES IN LANGUAGE
}

\author{
Prykhodchenko O. O. \\ Candidate of Philological Sciences, \\ Senior Lecturer at the Chair of Foreign Languages for Special Purposes \\ Zaporizhzhia National University \\ Zaporizhzhia, Ukraine
}

The main role of the person in the process of creation and development of the language system finds its representation in its inner laws. The dialectical nature of the development of the given structure made the principle of antinomisity one of its main axioms. This question was raised long ago, and now not only philosophers but also linguists are interested in this question. The study of such antinomies as «good - evil», «war - peace», «own - alien», «life - death» and others has a very important impact on the modern linguistics.

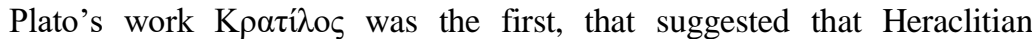
(objectivistic and onthologistic) and sophistic (subjectivistic and relativistic) visions of language are not only contrary to each other, but also complementary. But, this idea was too radical and innovatory for the time (and 